\title{
ADAPTIVE MANAGEMENT AS A TOOL OF SUSTAINABLE DEVELOPMENT
}

\section{Zhosan H. V.}

\section{INTRODUCTION}

Ukraine's economic situation is currently characterized by financial instability and high levels of risks, and, as a result, companies operating in the domestic market are forced to implement innovative types of management that can provide competitive advantages in a rapidly changing competitive environment, as well as the most effective interaction with external and internal environment, and ultimately the long-term survival of the enterprise.

The micro and macro environment of any modern enterprise presupposes a high degree of complexity, dynamism, and uncertainty. Regardless of the goals and strategy of the enterprise, whether it is a survival or maintaining a competitive position or development, it needs to look for ways to adapt to the environment. Therefore, the ability to adapt to changes in the external environment is the main success factor for an organization in business.

An effective management tool in an unstable economic situation, market unpredictability, and crisis will be adaptive management, which allows solving complex problems and make original and non-traditional management decisions.

Most Ukrainian enterprises do not realize the importance of adaptive management, and, accordingly, are not engaged in the development of adaptive management systems, tools, and methods of adaptation, as well as studying the problems of its improvement.

The formation of adaptive management of trade enterprises is a rather difficult task that requires appropriate methodological tools and a clear understanding of the internal mechanisms for the development of adaptive management processes. Thus, the issues related to the practical implementation of adaptive management in trade enterprises determine the relevance of the topic of the dissertation work.

To date, general theoretical foundations have not been developed in the field of adaptive management; there are no uniform approaches to determining the essence of adaptation and adaptive management, principles, classifications.

The following foreign authors have paid attention to the formation of adaptive management: G. Assel, B. Berman, S. Beer, P. Dixon, P. Drucker, 
R. Kanter, D. Callog, M. McDonald, T. Moth, D. North, M. Olson, M. Porter, K. Tateisi, J. Evans.

Theoretical and methodological problems of development of the system of adaptation of the mechanism of functioning of enterprises were covered by well-known specialists Alekseev S., Kozachenko A., Budnik M., Savina T., Kravchenko O., Krysko Zh., Antonov, Raevneva O., Stepanova Yu., Turitsa N. and others.

Despite the significant contribution of the above researchers to the theoretical and practical aspects of the formation of adaptive management, it can be stated that the issue has not been adequately studied.

\section{The relationship between sustainable development and adaptive management}

A modern knowledge-intensive enterprise is a complex socio-economic system operating in conditions of uncertainty, due to the constant variability of conditions, the emergence of new connections, the rapid reorientation of functioning in response to the dynamics of market needs. The need to take into account changes in the external environment in conditions of uncertainty leads to the need to apply adaptive management methods. In our opinion, the adaptive approach to management, integrating the most important elements of the process, system, and situational management approaches is their logical continuation. The main goal of adaptive management is to create additional capabilities of the system to respond to rapid changes in the external environment, to ensure the sustainable functioning and development of the organization. It can be argued that adaptive management is capable of orienting a knowledge-intensive enterprise to the demands and requirements of the market through the release of competitive products, which ensures its stable position. This approach requires considering the relationship between the economic categories "competitive advantage", "competitiveness", "economic sustainability".

The current level of development of market relations and increased competition in domestic and foreign markets make the problem of finding sources of maintaining economic sustainability, first of all, of the enterprises of the real sector of the economy especially urgent.

The economic sustainability of an industrial enterprise affects the entire economic system of the country, preserving its potential, ensuring its qualitative rise, entering international markets with new competitive products.

The scientific direction that studies the economic sustainability of industrial facilities is quite young. For the first time, the term "economic sustainability" arose in connection with the consideration of the problem of limited resources, which became a consequence of the global energy crises of 1973 and 1979. During its existence, this direction of economic thought turns 
into a separate discipline, which is called "ecosestate" ("economic security of state") ${ }^{1}$.

The problem of economic sustainability is actively considered in many scientific studies. The authors share the approach to the essence of economic sustainability proposed by Zaitsev O.N.: it is such a state of the enterprise, which retains the ability of effective functioning and stable progressive development under the negative impact of the external environment ${ }^{2}$.

Sharing this opinion, the authors offer their own concept of the economic sustainability of an enterprise - this is the ability of an enterprise to function effectively and develop steadily, being in equilibrium or close to it condition under the influence of external and internal environmental factors and offers their own approach to the essence of economic sustainability. This approach is conceptual in nature, since it assumes, when assessing economic sustainability, not only take into account the influence of the internal and external environment factors on the enterprise, but also manage these factors, creating a competitive advantage of the enterprise, the competitiveness of its products and ensuring economic sustainability in the future, that is, sustainability in functioning and sustainability in development of the enterprise. To achieve the economic sustainability of an enterprise, the ability of effective functioning and stable progressive development determines a constant renewal of products based on innovative potential, an increase in the technical and technological level of production, the use of modern methods of organizing and managing production, strengthening human resources, which allows the enterprise to be competitive and strengthen its position in market.

Sustainable development reflects the dynamic state of the economic system, which takes into account the time factor. The sustainability of the economic system at the current moment (sustainability of functioning) and sustainability of development (sustainability of the system in dynamics) is ensured by an adequate response to changes in the factors of the external and internal environment of the enterprise, which allows the enterprise to survive in a competitive environment and obtain a sufficient amount of profit for further functioning. Consequently, the sustainable development of an enterprise is based on the effective management of the enterprise's resources,

${ }^{1}$ Kozachenko A.V., Ponomarev V.P., Lyashenko A.N. (2013) Ekonomycheskaia bezopasnost predpryiatyia: sushchnost y mekhanyzm obespechenyia [Economic security of the enterprise: essence and mechanism of maintenance]. Kiev : Libra. 280 p.

${ }^{2}$ Kravchenko O. (2010) Pryntsypy pobudovy adaptyvnoi systemy upravlinnia pidpryiemstva $\mathrm{v}$ umovakh nestabilnosti ekonomiky [Principles of construction of adaptive management system of the enterprise in the conditions of instability of economy]. Collection of scientific works DETUT. Economics and Management Series. Ed. 15. P. 213-218. 
the range of products, which will ensure its competitive advantages and sustainable development.

The modern concept of competitive advantage is rooted in the early days of classical economics. Absolute advantage, focused on natural advantages, is the first step in the evolution of scientific views on competitive advantage. In this regard, Adam Smith's theory of relative advantage has played a fundamental role in the development of competitive advantage.

The first, who used the concept of competitive advantage was the famous American economist, academician of the Harvard Business School and member of the Presidential Commission on Industrial Competition Porter $\mathrm{M}^{3}$.

Porter M. in his research for the first time introduces the concept of "competitive advantage". By his concept, "competitive advantage is expressed in lower costs than competitors, or in the ability to change and control the price with a markup that exceeds the additional cost of price changes".

Since economic sustainability and competitiveness are interrelated concepts, the study of opinions on the issue of external and internal factors affecting the competitiveness, and, consequently, the economic sustainability of the enterprise, is of particular relevance.

It should be noted the great practical value of M. Porter's theory for substantiating the factors affecting competitive advantages and ensuring the competitiveness of economic entities set forth in M. Porter's monographs "International Competition", published in 1993 and "Competition", published in 2000.

The problem of assessing the competitiveness of an enterprise is more complicated than the problem of assessing the competitiveness of products, since it includes much more factors affecting the enterprise. In this regard, David Krevens suggests grouping factors according to the direction of functional processes: external (directed from the external environment to the inside of the organization), internal (coming from within the organization) and bilateral. External processes connect the organization with its external environment, providing feedback to it and forming external connections. Internal processes are aimed at meeting the needs of consumers. External processes also direct the competence of the organization, determined by internal and bilateral functional processes. The processes under consideration are characterized by many factors. This approach allows an organization to build its management structure focusing on cross-functional interaction ${ }^{4}$.

${ }^{3}$ Chandler A. (1964) Strategy and Structure: Chapters in the History of the American Industrial Enterprise. N.Y. : Newcomen Award, 347 p.

${ }^{4}$ Dumont G., Huzmezan M. (2002) Concepts, methods and techniques in adaptive control. American Control Conference, Vol. 2. P. 1137-1150. 
Based on the classical theory of M. Porter and the analysis of available works on the problem of competitiveness and competitive advantages, it is advisable to assume that the competitive advantage of high-tech production is expressed in lower costs of production and operation of high-tech products than competitors. Competitive advantages are the basis of the competitiveness of the products of a science-intensive enterprise and are provided through adaptive management based on the effective (economical) use of the enterprise's resources at all stages of the life cycle of a science-intensive product. Taking this into account, the following formulation of the essence of "product competitiveness" is proposed - it is the correspondence of product properties to the parameters of consumer demand, achieved as a result of adaptive management of competitive advantages in market conditions.

The author's concept of the category "competitiveness of a science-intensive enterprise" is the effective activity of an enterprise for the production and sale of high-tech science-intensive competitive products that are in demand in the market and fully satisfy consumer demand on the basis of adaptive resource potential management through the effective use of competitive advantages. The factors affecting the competitiveness and economic sustainability of the enterprise should be divided into direct and indirect factors. Direct influencing factors include consumers, competitors, suppliers, and the legal framework. Indirect factors are the general state of the economy within the geographic boundaries of the market, the political climate, the level of technologies used in the industry, the availability of a labor market and qualified personnel. All these factors do not depend on the activities of the enterprise and therefore they can be attributed to external factors.

The concepts of competitive advantage and competitiveness are closely interrelated and mutually defining concepts. External and internal factors affecting the competitiveness of an enterprise also determine its economic sustainability.

Competitive advantages are provided by the enterprise due to the management of internal factors through the efficient use of enterprise resources. The competitiveness of products and the competitiveness of the enterprise are the basis for economic sustainability. Based on this, the following classification of internal factors that form its competitive advantages and affect the sustainability of high-tech production is proposed (Fig. 1.1). The economic sustainability of high-tech production is primarily ensured by innovative sustainability - this is a general line, a system of strategic measures to ensure sustainable development and operation of the enterprise. Research and development works are the basis for the creation and development of new products, materials, the modernization of products, and the development of new, progressive technological processes, the improvement of the used technological processes, complex mechanization 
and automation of production processes. Organizational and managerial sustainability, according to the authors, is aimed at improving the organization of production and management to increase the efficiency of the use of material, fuel and other resources of the organization, improve cooperation and division of labor, organize the maintenance of workplaces, and introduce advanced techniques and methods of labor. Technical sustainability provides for the renewal and modernization of fixed assets, an increase in the level of use of fixed assets and production capacities. Financial sustainability is characterized by the ability of an enterprise to meet its financial obligations. Personnel sustainability provides for the sustainability of the personnel composition, stability and qualification potential of the personnel. Consequently, in a broad sense, the economic sustainability of a knowledgeintensive manufacturing enterprise is interpreted as a set of levels of financial, innovation, technical and personnel sustainability, the presence of which allows the subject to conduct fundamental and applied scientific research, to a large extent form external conditions, improve the performance of scienceintensive products and ensure its competitiveness in the long run.

External and internal factors affecting the enterprise are interrelated. On the one hand, external factors affect the internal, on the other - the management of internal factors has a positive effect on external ones.

Thus, the company can manage internal factors to smooth out the negative effects of external factors, i.e. due to competent management the enterprise can adapt to changes of external environment and remain in a steady condition. The main lever of adaptive management should be the innovative potential of the enterprise. The sustainable development of a knowledgeintensive enterprise is primarily ensured by the desire for new knowledge, an increase in the technical state, and competition at the same time acts as a stimulating function. It is the competition, which, as K. Marx noted, is of a coercive nature that makes the enterprise look for new, more advanced technologies and techniques, create new ones, and improve old goods and services. Competition is a powerful force that stimulates the process of renewal and development that lead to the achievement of a competitive advantage of the enterprise. Thus, competition and innovation are not identical, but interrelated and interdependent.

A huge role in the development of competition was played by the transition to a market orientation in the $30 \mathrm{~s}$ of the last century. In relations between the consumer and the manufacturer, the role of the consumer has sharply increased, and the manufacturer was forced to look for ways to survive in the face of market uncertainty. 


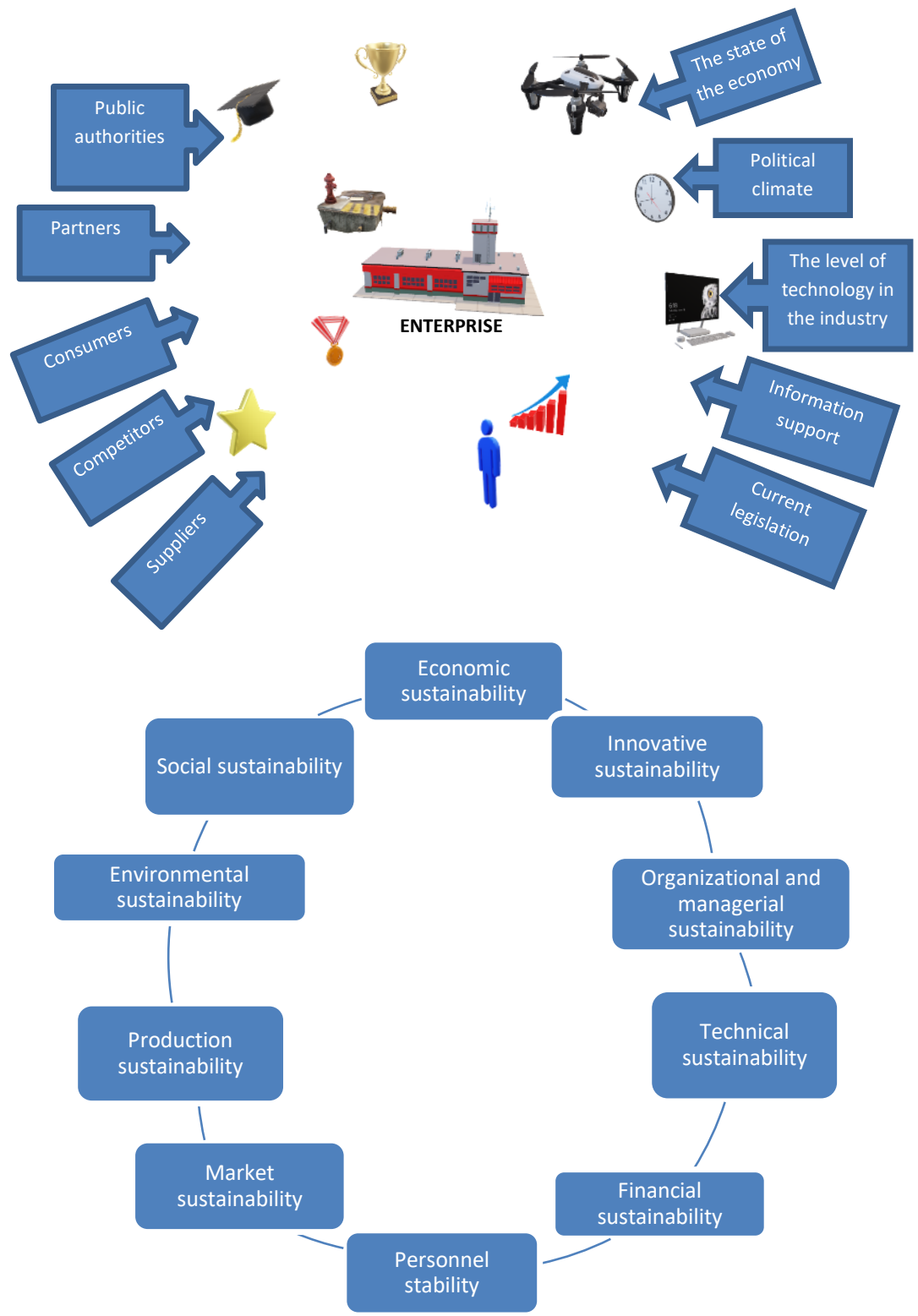

Fig. 1.1. Factors influencing the sustainability of enterprise development 
As Ansoff notes, for successful functioning the manufacturer was forced to develop new types of products, quickly change the assortment. Thus, as a result of a greater focus on the demands and requirements of the market, there was a significant increase in the diversity of both the external and internal environment of the enterprise, and the existing management systems were unable to cope with this 5 .

Consequently, adaptive management appeared in response to the need of an enterprise to take into account the influence of factors of competitive nature and take proactive measures to ensure competitive advantage, competitiveness and achieve a stable state of the enterprise through effective management of internal factors of sustainability.

Following the proposed concept of competitive advantage, the authors believe that the concept of adaptive management should be built on the economical use of the resources of a knowledge-intensive enterprise, using the most of the internal reserves.

Thus, adaptive management can be viewed as a means of ensuring the sustainable operation and development of an enterprise.

Each component of economic sustainability should become the object of adaptive management. The mechanism for implementing adaptive management is the adoption and implementation of management decisions. Only on the basis of scientifically grounded approaches to making and executing managerial decisions will the directions of research and development work on the development of new products, new technological processes and improvement of manufactured products and applied technology, and improvement of production organization be selected. In his book "Management decisions" Fatkhutdinov R.A. names 20 scientifically based approaches to management decisions to manage the competitiveness of an enterprise.

As one can see, the adaptive approach to management appeared in response to the increased diversity of the external and internal environment of the enterprise, to its need to adapt to the demands of the market and as a means of ensuring a sustainable state and development. Since the adaptive approach to management appeared relatively recently, therefore, many theoretical and methodological provisions of this approach have not yet been sufficiently developed, which requires a deeper consideration of the theoretical foundations of adaptive management.

The relationship of enterprise sustainability with competitiveness and adaptive management is shown in Fig. 1.2.

${ }^{5}$ Sulek A. (1994) Do czego su sondae? Wykorzystanie bada opinii publicznej w kampanii wyborczej 1993. Kultura i Spoeczestwo, vol. 38(3). P. 103-117. 


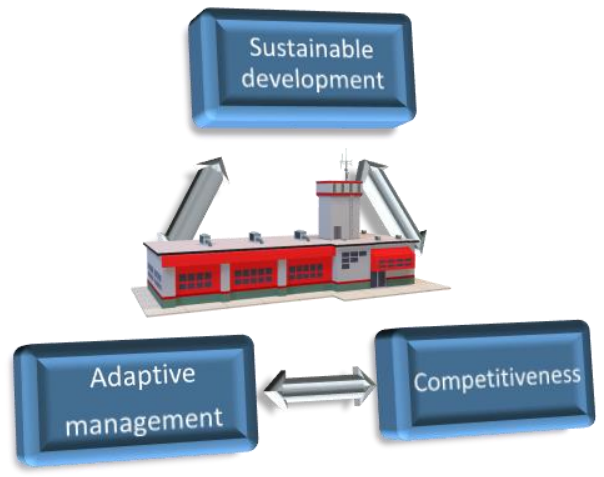

Fig. 1.2. Relationship between sustainability, competitiveness and adaptive management

\section{Adaptive management as a tool to increase the sustainability of enterprise development}

In nonlinear dynamic systems, which include business entities, the external environment always plays a decisive role in relation to the structures located in it and affects the rate of their self-organization. In this case, the most important condition is constant adaptation to the requirements of the external environment ${ }^{6}$. Evolution is associated with the achievement of a stable state of the system, in which the latter enters into equilibrium with the environment. This process is due to the fact that the rate of change in external conditions, as a rule, is lower than that of the system. Adaptation usually results in increased system versatility. Thus, the adaptive approach involves considering the system from the standpoint of its preservation and development, despite the ongoing transformations. At the same time, a reduction method is used, which at its core is design, knowledge based on existing developments of different directions. The need for its application is due to the fact that any theory is correct only for some time, and then gives way to a new one, as evidenced by the entire evolution of sciences. In contrast to the reduction method, the complementary method in theories is considered as a transitional one, since, examining the subject from the point of view of the constructions available in various sectors of science, it defines a new direction.

${ }^{6}$ Doing Business - 2020. (2019) Zavdiaky chomu Ukraina pidnialasia v reitynhu na 64 skhodynku [Due to which Ukraine rose to 64th in the ranking. Union of Ukrainian Entrepreneurs], Economic Truth. URL: https://www.althoughda.com.ua/publications/2019/ 10/24/652929/ (access date: October 24, 2019). 
Adaptability, as a form of system behavior, contributes to its selforganization, the consolidation of the property that determined the creation of an object, its successful existence and development in evolutionary transformations.

Adaptive systems belong to the class of self-organizing and are characterized by the ability to change the order and structure depending on the nature of the influence of external factors. The principles of self-organization, being dominant in the emerging synergetic concept of management, mark the emergence of a new approach based on the classical (cybernetic) one.

It also features the uncertainty of the environment, the network nature of structures, and the virtualization of business processes. A comprehensive consideration of the essence, content of finance as an economic category and the provisions of systems theory allowed us to highlight the properties of their adaptive impact.

It should be taken into account the cost nature of resources, theirs presentation and adaptive focus of functioning. The provisions relate to nonformalized constructions, and the adaptive design of the activities of an economic entity is a formalized material. This concept assumes both an analytical consideration of the situation and its figurative vision, depending on the degree of personality development and the experience of the leader.

According to Astrom K., the essence of management is design, which, in turn, involves creative freedom of action, the ability to make changes to the system. Design “... means managing the levers that determine the level of division of labor and coordination mechanisms and thus the functioning of the organization." It is also logical that "it is easier to pre-program development than to significantly change the dynamics of an already fully formed system".

The design of financial flows should be based on the social division of labor as the primary reason for the formation of rational management influences in this area of the enterprise.

This approach, as well as the presentation of the system as dynamic (assuming the determination of reproductive processes in the elements) allows taking into account the peculiarities of its functioning. Design as a formalized program of actions cannot take into account all the parameters of the system under consideration. With its adaptive implementation in terms of the financial activity of the enterprise, the following main elements of the system become important: an object, a subject, and a management process.

The allocation of an object - financial resources - is due to the fact that, being exposed to managerial influence, it orients the system towards achieving a goal (which has a cost estimate), predetermines the order and parameters of functioning that correspond to external conditions and constraints. The initial parameters of the object determine the principles of derivative construction, structuring and integration of the system. The decisive influence of the 
structure of financial resources on the form of business organization, its integration into the macrosystem is important. The expression "the end determines the means" applies here. The goal is in terms of value, and the means are all other components of the financial base of the enterprise.

Since the resources of an enterprise are a value formation, then when using them as a defining element, parameters are taken into account that increase the effective assessment of the business (minimum costs and maximum profit for any type of resources), corresponding to the form of attracted funds, and the objective, essential characteristics of the education received become profit and cost. It seems expedient to measure the efficiency of the functioning of the system by means of comparing the costs associated with the use of the entire set of resources and the profits. These characteristics become universal for any elemental set, the form gives an idea of the costs and benefits obtained as a result of considering various combinations of resources. The matrix, assuming the arrangement of funds (real, potential) within the selected set of them, makes it possible to control the state of the system, calculate the efficiency of value growth and reproduction of financial resources.

When designing the subject of control (control subsystem), it is necessary to achieve full compliance of its activities with the specifics of the functioning of the object. This is how the potentialities of value education are fully realized in the chosen target direction. The subject of management initiates the processes of structure formation, ensures the implementation of the reproductive process of the system (stages of formation and use), which predetermines its viability and implementation of functions.

According to the provisions of cybernetics, the diversity of control systems is less than the diversity of the control object in terms of information "capacity". The framework of adaptive behavior is due to the fact that the control system is smaller than the object it is designed to streamline, therefore, only in an ideal case, detailed control of financial flows is possible. This feature of the functioning of the system presupposes the presence of a limit of diversity, below which the effective performance of the functions of the system is impossible. The uncertainty in the behavior of the controlled object is reduced due to the diversity of the control body. There is also a limit to such differentiation, otherwise the costs of the management subsystem may exceed the income received from the management of the object. Diversity is achieved by matching the characteristics of the control object.

The methodological principle of the formation of the system and its management, implemented in the process of adaptive design, takes into account the following theoretical and practical requirements for the corresponding functions: differentiation in relation to the focus on the control object; no duplication; compliance with the object of influence; determination of the form and content of financial resource management. 
Thus, the management function as an objective category, formed at the intersection of one of the phases of the management cycle and the stage of the reproductive process, is an area of the information population. The amount of information by function depends on the element base of the resource system and is determined by a set of tasks set by the subject. It is obvious that the state of financial resources characterizes the degree of division of labor as a particular level of elemental decomposition of the reproduction system. Specialization processes can be attributed to specialized management functions, and cooperation - to their interconnection. Such interpretations make it possible, from a scientific point of view, to approach the distribution of functional responsibilities of financial managers and to design organizational structures for managing resource flows in their relationship with management objects, thereby achieving compliance of the controlled and controlling subsystems, taking into account the diverse features of functioning and reproduction. This solves the problem posed by J.C. Dumont: "The complexity of the structure of an organization as a social system is manifested both in the functional division and coordination of activity horizontally, and in the hierarchy of its structure along the vertical".

The complex nature of financial activities at an enterprise implies, in addition to the specialization of management personnel, the need to coordinate all processes (this is the prerogative of the highest level of management - top management). The system must have a professionally trained leading subject of management, ensuring its development as a holistic entity and preventing the processes of disintegration, imbalance, restructuring, and bankruptcy. The coordination contour combines the management and design of the financial activities of the enterprise in order to "... balancing competing goals, to achieve the optimal result for the company as a whole". Its functions include: forecasting, decision-making, drawing up a general work plan, recruiting, coordination, monitoring performance and motivation.

For the development of self-organizing processes and the formation of synergistic properties of the system in the arsenal of the adaptive concept, there is a number of management technologies: cost reengineering methods, a variety of types of organizational structures, appropriate strategic management tools, spatio-temporal coordination of components in financial and credit transformations of an evolutionary economy. The implementation of management functions, depending on the level of consideration, has certain specificity. Strategic and tactical activities of managers are carried out through the use of various types of budgets, reflecting the state of the resource system relative to the planned level, bringing analytical indicators and monitoring tools for individual work areas.

The projected parameters should take into account the main promising directions of development of finance for foreign companies: strategic planning 
focused on value growth; system of budgets and balanced scorecards. An integral part of adaptive design should be considered taking into account the cyclical factor of the existence of the system, which means the implementation of an evolutionary approach to its development. Interesting from the point of view of ideas on the cyclical functioning of the system and the growth of its cost should be considered the position of A. Chandler, who singled out in the version of the life cycle phases characteristic of relationships with the external environment: expansion of operations and accumulation of funds; rationalizing resources; expansion into the sphere of new markets, creation of new structures.

The life cycle of any system includes the stages of birth, maturity, and death. Processes internal to the system and its stages presuppose such phases (waves) as rise, crisis, and depression. The cycles external to the system are determined by the parameters of the environment that determine it and assume waves similar to the internal ones. This determines the main cyclical fluctuations.

The adaptability of the system increases with an increase in its size and degree of diversification, which determine the objective processes of expansion and a permanent influx of ordered information, which increases the levels of its entropy and viability. Integrated formations make it possible to smooth out many cyclical fluctuations that are possible with separate functioning of participants, by improving capital turnover in industries, reorienting funds from unprofitable industries to growing market segments, eliminating seasonality, etc.

Design features are not just a collection of specific methods of management and reengineering of finance, philosophy and corporate culture, but already an intangible asset, a kind of business system that streamlines information and financial relationships to increase the value of the organization. Thus, the category of adaptability involves considering the system of financing an economic entity from the standpoint of preservation and development, despite the negative changes in its external environment. The peculiarities of the functioning of the financial mechanism of an enterprise are determined by the types of designed structures. The scheme for including a tunable model in the control loop ensures the constancy of the dynamic characteristics of the system as a whole when changing the environmental parameters. This compares the results with the metrics obtained using the custom model. The difference between them is introduced into the negative connection circuit, after which the control actions are adjusted. 


\section{CONCLUSIONS}

Successful development of enterprises in the conditions of constant changes of environment, formation and improvement of potential are conditioned by force of interconnection and effective interaction of business processes. The obligatory consideration of the synergetic effect from the interaction of all elements of business allows not only to approach the use of resources economically, but also to improve the mechanism of adaptive strategic management, to justify the vectors of development.

In accordance with the above, customizable models can be used to compensate for the harmful effects of delays in the control object on the sustainability of the process itself, laying in them the possibility of anticipating events (including undesirable). To solve this problem, it is promising to use the methods of neural networks that predict the behavior of the system at given perturbations and various control laws, which will allow selecting self-tuning optimal control options.

For this purpose, branched algorithms can be used, where controls and models are attributed to their procedural part. There can also be a choice of alternative business plans, risk analysis. The above models must operate in the mode of periodic solution of the control problem in an accelerated time scale to search all options in a format not exceeding the period of discreteness. A systematic approach, combined with adaptive management tools, will undoubtedly help to increase the sustainability of economic entities.

\section{SUMMARY}

The article considers adaptive management as a tool for sustainable development. The successful development of enterprises in the conditions of constant changes in the environment, the formation and improvement of capacity due to the strength of the relationship and the effective interaction of business processes are researched. The obligatory consideration of the synergetic effect from the interaction of all elements of business allows not only to approach the use of resources economically, but also to improve the mechanism of adaptive strategic management, to justify the vectors of development.

\section{REFERENCES}

1. Doing Business - 2020. (2019) Zavdiaky chomu Ukraina pidnialasia v reitynhu na 64 skhodynku [Due to which Ukraine rose to 64th in the ranking. Union of Ukrainian Entrepreneurs], Economic Truth. URL: https://www. althoughda.com.ua/publications/2019/10/24/652929/ (access date: October 24, 2019).

2. Savina T.N. (2015) Kontseptualni zasady metodolohii doslidzhennia sotsialno vidpovidalnoho investuvannia [Conceptual bases of methodology of 
research of socially responsible investing]. Economic analysis: theory and practice. 2015. № 9. P. 52-61.

3. Lvova N.A. (2019) Otvetstvenniy investytsyy: teoryia, praktyka, perspektyvy [Responsible investments: theory, practice, prospects]. Scientific journal of ITMO National Research Institute. Series: Economics and Environmental Management. 2019. № 3. P. 76-86.

4. Maibutnie, yake na nas chekaie. Chomu bez prohram staloho rozvytku $\mathrm{v}$ biznesi nemaie perspektyv [The future that awaits us. Why there are no prospects in business without sustainable development programs.] URL: https://nv.ua/eng/biz/markets/maybutnye-dlya-biznesu-staliy-rozvitokshcho-potribno-znatipro-nogo-vzhe-sogodni-eksperti-50083754.html (access date: April 26, 2020).

5. Orlova N.S., Kharlamova A.A. (2014) ESG-pryntsypy vedennia biznesu vykhodiat na pershyi plan. Yak ekolohichni, sotsialni ta upravlinski kryterii vplyvaiut na stalyi rozvytok kompanii. Shcho potribno znaty pro nykh vzhe zaraz [ESG-principles of doing business come to the fore. How environmental, social and management criteria affect the company's sustainable development. What you need to know about them now.] URL: http://elibrary.kubg.edu.ua/id/eprint/13031/7/N_Orlova_M_2_IS.pdf (access date: April 26, 2020).

6. Otvetstvennoe ynvestyrovanye stanovytsia vse bolee vlyiatelnoi ydeolohyei [Responsible investing is becoming an increasingly influential ideology.] URL: https://investinfra.ru/novosti/otvetstvennoe-investirovaniestanovitsya-vse-bolee-vliyatelnoyideologiey. html (access date: June 7, 2019).

7. Budnik M.M. (2012) Adaptatsiia promyslovykh pidpryiemstv do rynkovykh umov hospodariuvannia [Adaptation of industrial enterprises to market conditions of management]: author's ref. dis. ... Ph.D. in Economics: special. 06/08/01 Kharkiv, 19 p.

8. Kozachenko A.V., Ponomarev V.P., Lyashenko A.N. (2013) Ekonomycheskaia bezopasnost predpryiatyia: sushchnost y mekhanyzm obespechenyia [Economic security of the enterprise: essence and mechanism of maintenance]. Kiev: Libra. 280 p.

9. Stepanova Yu. L. (2007) Poniattia adaptatsii pidpryiemstva [The concept of enterprise adaptation.] Economy. Management. Entrepreneurship. № 18 (II). P. 57-61.

10. Turitsa N.A. (2009) Stratehichni chynnyky adaptatsii pidpryiemstv do zovnishnoho seredovyshcha (na prykladi miasopererobnykh pidpryiemstv) [Strategic factors of adaptation of enterprises to the external environment (on the example of meat processing enterprises):] author's dis. ... Ph.D. in Economy: special. 08.00.04. Odessa, 20 p. 
11. Antonov V.N., Terekhov V.A., Tyukin I.Y. (2001) Adaptyvnoe upravlenye $\mathrm{v}$ tekhnycheskykh systemakh [Adaptive control in technical systems]. Saint-Petersburg: St. Petersburg University Press, 244 p.

12. Grunin O. A., Kuprin A.A. (2010) Formyrovanye adaptyvnosty system upravlenyia orhanyzatsyei predprynymatelskoho typa [Formation of adaptability of management systems of the organization of business type.] St. Petersburg: Asterion, $188 \mathrm{p}$.

13. Kravchenko O. (2010) Pryntsypy pobudovy adaptyvnoi systemy upravlinnia pidpryiemstva $\mathrm{v}$ umovakh nestabilnosti ekonomiky [Principles of construction of adaptive management system of the enterprise in the conditions of instability of economy]. Collection of scientific works DETUT. Economics and Management Series. Ed. 15. P. 213-218.

14. Orlova K.E. (2015) Vyznachennia mekhanizmu adaptatsii pidpryiemstv do umov zovnishnoho seredovyshcha [Definition of the mechanism of adaptation of the enterprises to environmental conditions.] Innovative economy. № 5. P. 174-178.

15. Pogorelov Yu. S. (2019) Modeliuvannia rozvytku pidpryiemstva. [Modeling of enterprise development.] Current economic problems. № 10. P. 51-59.

16. Gonchar O.I. (2015) Funktsionalno-orhanizatsiini aspekty upravlinnia potentsialom pidpryiemstva na zasadakh synerhetyky [Functional and organizational aspects of enterprise potential management on the basis of synergetics.] Scientific Bulletin of Polissya. № 1 (1). Pp. 77-84. URL: https://www.google.com/search?newwindow=1\&rlz=1C1CHBD_ruUA908 UA908\&sxsrf (access date: June 7, 2019).

17. Sulek A. (1994) Do czego su sondae? Wykorzystanie bada opinii publicznej w kampanii wyborczej 1993. Kultura i Spoeczestwo, vol. 38(3). P. 103-117.

18. Tyukin I.Y., Terekhov V.A., (2008) Adaptatsyia v nelyneinykh dynamycheskykh systemakh [Adaptation in nonlinear dynamical systems.] $\mathrm{SPb}$. : LKI, $384 \mathrm{p}$.

19. Astrom K.J., Wittenmark B. (1994) Adaptive Control. N. Y.: AddisonWesley Publishing Company. $652 \mathrm{p}$.

20. Efimov D.V. (2005) Robastnoe y adaptyvnoe upravlenye nelyneinymy kolebanyiamy [Robust and adaptive control of nonlinear oscillations.] Saint Petersburg : Nauka, $314 \mathrm{p}$.

21. Yurevich E.I. (2007) Teoryia avtomatycheskoho upravlenyia [Automatic control theory.] Saint Petersburg : BXB-Petersburg, 560 p.

22. Dumont G., Huzmezan M. (2002) Concepts, methods and techniques in adaptive control. American Control Conference, Vol. 2. P. 1137-1150.

23. Chandler A. (1964) Strategy and Structure: Chapters in the History of the American Industrial Enterprise. N.Y. : Newcomen Award, 347 p. 
24. Zhosan G., Kyrylov Y., Tanklevska N., (2018) Viral management as a subset of creative management in conditions of financial instability. Scientific Bulletin of Polissya. № 2 (14). Part. 2. P. 160-164. URL: http:// irbis-nbuv.gov.ua/ASUA/0067396

\section{Information about the author: Zhosan Hanna Volodymyrivna, $\mathrm{PhD}$ in Economic,} Associate Professor at the Department of Management and Information Technologies Kherson State Agrarian and Economic University 23, Stretenskaya str., Kherson, Ukraine, 73006 orcid.org/0000-0002-3577-6701 